\title{
Migration as feminisation? Chinese women's experiences of work and family in Australia
}

\section{Christina Ho}

Social Inquiry, Faculty of Humanities and Social Sciences

University of Technology, Sydney

Australia

Correspondence to:

Christina Ho

Social Inquiry, Faculty of Humanities and Social Sciences

University of Technology, Sydney

PO Box 123

Broadway NSW 2007

Australia

Tel +61-2-9514-1946

Email: christina.ho@uts.edu.au 


\title{
Migration as feminisation? Chinese women's experiences of work and family in Australia
}

\begin{abstract}
Like many Western governments, the Australian government increasingly views migration through the lens of economic efficiency, arguing that skilled professionals achieve the best employment outcomes and therefore constitute the ideal migrant. This paper challenges these claims, showing that skilled migrants do not always successfully transfer their skills to new labour markets. It argues that the government's 'success story' narrative disguises a much more complex reality, in which migrants' employment outcomes are shaped by broader social and cultural factors, as well as just economic ones. In particular, it shows that men and women typically experience migration differently, and the challenges of re-negotiating work and care in a new setting often lead to a 'feminisation' of women's roles, as they find themselves taking up more traditional gender roles as wives and mothers. Using in-depth interviews and survey data from the Australian Government, I show that in Australia, migrant women often experience downward occupational mobility and a re-orientation away from paid work and towards the domestic sphere.
\end{abstract}




\section{Migration as feminisation? Chinese women's experiences of work and family in Australia}

Around the Western world, governments have increasingly used economic criteria to select migrants, arguing that migrants with high levels of human capital are best able to contribute to the national economy. Australian governments have been committed to this policy direction, and over the last two decades, have reshaped the country's migration program to increase the emphasis on skilled migration. Skilled professionals now comprise the majority of new arrivals to Australia, and the government claims that these migrants are achieving unprecedented success in employment outcomes, with high labour force participation and low unemployment rates.

This paper challenges these claims, showing that skilled migrants do not always successfully transfer their skills to new labour markets. It argues that the government's 'success story' narrative disguises a much more complex reality, in which migrants' employment outcomes are shaped by broader social and cultural factors, as well as just economic ones. In particular, it shows that men and women typically experience migration differently, and the challenges of re-negotiating work and care in a new setting often lead to a 'feminisation' of women's roles, as they find themselves taking up more traditional gender roles as wives and mothers. ${ }^{1}$ Using in-depth interviews and survey data from the Australian Government, I show that in Australia, migrant women often experience downward occupational mobility and a re-orientation away from paid work and towards the domestic sphere.

\section{Challenging the 'success story' of skilled migration}

In the last decade, governmental and academic discourse on migrant employment has been dominated by a 'success story' narrative of Australia's skilled migration program. Both the national government and key academic researchers (Cobb-Clark 2000, 2001; Cobb-Clark and Chapman 1999; Richardson et al 2001, 2002; VandenHeuvel and Wooden 1999, 2000) have argued that new arrivals, who are more highly skilled than 
ever before, are increasingly achieving successful outcomes in the Australian labour market.

These claims are generally based on data from the Longitudinal Survey of Immigrants to Australia (LSIA), a government-commissioned study of the experiences of several thousand migrants during their first few years in Australia. ${ }^{2}$ Informed by human capital theory, researchers typically use multivariate statistical analysis of the LSIA data to examine how individual attributes of migrants affect their labour market outcomes. They show that employment outcomes generally improve with higher levels of human capital, operationalised as educational qualifications and English language ability. Thus it is argued that migrants with higher levels of qualifications and English proficiency achieve better outcomes in terms of employment and unemployment rates, earnings, and occupational status.

For example, VandenHeuvel and Wooden (2000: 64) show that three and a half years after arrival, migrants with a degree were more than 20 percentage points more likely to be in the labour force than those with no post-secondary qualifications. They also show that almost three quarters of migrants with good English speaking skills were in the labour force, compared with only about half of those with poor English speaking skills (VandenHeuvel and Wooden 2000: 64). Overall, researchers show that migrants entering Australia in the skill stream of the migration program outperform those in the family and humanitarian streams. The former have higher labour force participation rates, lower unemployment rates, and higher incomes and occupational status (Cobb-Clark and Chapman 1999; Richardson et al 2001; VandenHeuvel and Wooden 1999, 2000; Williams et al 1997).

These findings are championed by the Australian government, which argues that they vindicate the emphasis on human capital in migrant selection. The Department of Immigration and Multicultural and Indigenous Affairs (2001: 2) states that LSIA findings 'strongly suggest that a program which is weighted more towards skilled migration will have better overall labour market outcomes and thus a better economic impact than a program which is weighted towards family reunion migration. Recognising these factors, 
the Australian Government has shifted the balance of the migration program towards skilled migration (the Skill Stream) and away from family reunion (the Family Stream)'.

Skilled migrants inevitably have some advantages in the labour market over unskilled migrants. However, is human capital the only determinant of migrant employment outcomes? What is the role of migrants' household contexts, for example, or of gender ideologies about the appropriate roles of men and women at work and at home? These are questions that this literature does not explore, because of its individualistic focus, and its assumption that individuals' human capital and their labour market outcomes are directly and causally linked. This approach is particularly inadequate for explaining migrant women's experiences.

Social scientists examining women and migration have shown the importance of broadening the focus of research to include the household context, and wider social and cultural factors, such as gendered divisions of labour in the family and national workforce. These scholars have shown that while migration can bring new opportunities and freedoms for women, it is usually women who bear the brunt of the burdens of adapting to life in a new country. While international migration is often a 'career move' for men, women, who frequently migrate as dependent spouses, commonly subordinate their own careers to facilitate their family's re-settlement (Lam 1994; Lee et al 2002; Mak 2001; Man 1995, 1997, 2004; McLaren and Dyck 2004; Meintel et al 1987; Pe-Pua et al 1996; Raghuram and Kofman 2004; Salaff and Greve 2003, 2004; Yeoh and Khoo 1998; Zhou 2000).

My research builds on this literature, using in-depth interviews with Chinese women and LSIA data, to show that even skilled women, accustomed to being active in the workforce, commonly experience downward occupational mobility in Australia, together with an escalation in domestic workloads, as they find themselves solely responsible for previously shared tasks. Ultimately, these changes lead women to redefine their roles and identity, the process I term 'feminisation'. 


\section{Methodology}

This paper relies primarily on qualitative data gained through in-depth interviews conducted between 2001 and 2003. Twenty-two interviews were conducted with women from Hong Kong and 22 with women from China, these two birthplaces representing the largest populations of Chinese migrants in Australia. Although a sample of 44 cannot be representative of the total population of these groups, it does allow for an adequate range of demographic characteristics and experiences to be covered. All respondents resided in Sydney, Australia's most popular migrant destination, at the time of interview, and were mostly aged in their 30s or 40s. The median length of time the PRC women had spent in Australia was five years, for the Hong Kong women, it was 12 years.

I recruited respondents using the snowball technique, whereby respondents were asked to recommend other women to be interviewed. This technique was the most appropriate because the interviews included quite personal questions, meaning that establishing rapport and trust was crucial. The initial interviewees comprised members of my own personal networks, including family friends and clients of community organisations with which I had been involved.

Interviews were semi-structured and lasted typically one to two hours. More than half (28) of the respondents were interviewed in English. The remainder were interviewed in Cantonese (10) and Mandarin (6), with the assistance of an interpreter. The next section outlines the key changes in these women's work experiences after migration to Australia.

\section{The decline in Chinese women's paid work after migration}

Women in both Hong Kong and China have a strong history of engagement in paid work. Since the 1960s, the Hong Kong economy has relied on industries employing substantial numbers of women, such as light manufacturing and services. More generally, women's labour force participation has been supported by a consistently buoyant economy and shortages of labour, due to declining birth rates and the brain drain of emigrating 
professionals (Man 1997). In China, 50 years of government policy encouraging women into the workforce has generated almost universal female employment in urban areas. In the 1980 s, 90 per cent of urban women were working, one of the highest rates in the world (Bauer et al 19902). And in the last two decades, China's economic boom has created a large number of jobs for women in cities and in dynamic rural regions. Thus as Zhou argues, 'paid employment is an indispensable part of womanhood for contemporary mainland Chinese... The current generation of Chinese women grew up believing that working outside the home is the only way of life' (2000: 449).

In addition to their long histories of active labour force participation, Chinese women migrating to Australia are typically highly educated. The 2001 Australian census showed that 25 per cent of Hong Kong-born women and 21 per cent of China-born women had a university degree, compared to 13 per cent for the total Australian female population (unpublished ABS census data). Among recent migrants, LSIA data shows that the vast majority of Chinese women have post-school qualifications (67 per cent for those from Hong Kong women, 70 per cent for women from China) (unpublished LSIA data).

Despite these credentials, migration often entails a reduction in Chinese women's paid employment. This has been documented in many Western countries, including the United States, Canada and Australia (Lam 1994; Mak 2001; Man 1995, 1997, 2004; Pe-Pua et al 1996; Salaff and Greve 2003, 2004; Zhou 2000). These studies have found that language difficulties, non-recognition of overseas gained qualifications, racial and sex discrimination, and devaluation of overseas work experience often result in downward occupational mobility or unemployment for Chinese women after migration. In addition, as many of these studies highlight, the loss of family and social support networks, for example, mothers, mothers in law, or hired domestic help, means that women must take sole responsibility for managing and performing household labour. Women's increased household responsibilities reduces their time for pursuing employment-related or social activities and is often seen by women as equivalent to accepting a more traditional female role. 
My own research on Chinese women in Australia confirms these patterns. My quantitative and qualitative data indicate that it is common for women to leave the workforce entirely after migration, or shift from full-time to part-time work, reorienting their energies toward the domestic sphere of the family. ${ }^{3}$

My analysis of LSIA data shows that while Chinese women had high levels of premigration employment (relative to other female migrants), this changes dramatically after migration. In Australia, a much smaller proportion of women from Hong Kong and China are employed, while the proportion engaged in home duties increases substantially. This is particularly the case for PRC respondents, only a minority of whom are employed, even after more than three years in Australia. Table 1 shows these patterns for female primary applicants, while Table 2 depicts the experiences of migrating unit spouses, who experience an even more dramatic fall in employment rates. ${ }^{4}$

Table 1: Main activity of female primary applicants from Hong Kong and China, before and after migration $(\%)$

\begin{tabular}{|c|c|c|c|c|c|c|}
\hline \multirow[t]{3}{*}{ Main activity } & \multicolumn{2}{|c|}{$\begin{array}{c}12 \text { months prior } \\
\text { to migration } \\
N=156\end{array}$} & \multicolumn{2}{|c|}{$\begin{array}{c}6 \text { months after } \\
\text { migration } \\
N=158\end{array}$} & \multicolumn{2}{|c|}{$\begin{array}{c}31 / 2 \text { years after } \\
\text { migration } \\
N=157\end{array}$} \\
\hline & China & Hong & China & Hong & China & Hong \\
\hline & & Kong & & Kong & & Kong \\
\hline Employed & 59 & 84 & 19 & 39 & 22 & 55 \\
\hline Unemployed & 4 & - & 9 & 6 & 5 & 2 \\
\hline Home duties & 24 & 10 & 48 & 37 & 37 & 35 \\
\hline Other & 13 & 6 & 24 & 18 & 36 & 8 \\
\hline Total & 100 & 100 & 100 & 100 & 100 & 100 \\
\hline
\end{tabular}

Source: LSIA1, Waves 1 and 3

Table 2: Main activity of female migrating unit spouses from Hong Kong and China, before and after migration $(\%)$ 


\begin{tabular}{|c|c|c|c|c|c|c|}
\hline \multirow[t]{3}{*}{ Main activity } & \multicolumn{2}{|c|}{$\begin{array}{c}12 \text { months prior } \\
\text { to migration }\end{array}$} & \multicolumn{2}{|c|}{$\begin{array}{c}6 \text { months after } \\
\text { migration } \\
N=103\end{array}$} & \multicolumn{2}{|c|}{$\begin{array}{c}31 / 2 \text { years after } \\
\text { migration } \\
N=106\end{array}$} \\
\hline & China & Hong & China & Hong & China & Hong \\
\hline & & Kong & & Kong & & Kong \\
\hline Employed & 88 & 64 & 19 & 13 & 24 & 27 \\
\hline Unemployed & - & - & 2 & 9 & 26 & - \\
\hline Home duties & 10 & 36 & 47 & 69 & 38 & 63 \\
\hline Other & 2 & - & 32 & 9 & 12 & 10 \\
\hline Total & 100 & 100 & 100 & 100 & 100 & 100 \\
\hline
\end{tabular}

Source: LSIA1, Waves 1 and 3

In comparison, male primary applicants from China and Hong Kong experience a smaller reduction in labour force participation. In fact, migration to Australia widens the gender gap in employment rates for these groups. For example, while the overall proportion of Hong Kong respondents in employment was very similar prior to migration (84 per cent for women, 85 per cent for men), after three and a half years in Australia, this gap had widened considerably (55 per cent for women, 79 per cent for men) (unpublished LSIA data).

Australian Census data show that Chinese women have a lower labour force participation rate than their male counterparts, and the total Australian population, as Table 3 shows. In 2001, the participation rates for Hong Kong- and China-born women were both more than 10 percentage points lower than for their male counterparts, and up to eight percentage points lower than for all Australian females (ABS 2003).

Table 3: Labour force participation rate for the Hong Kong- and China-born and total Australian population, by gender, 2001 (\%)

\begin{tabular}{lcc}
\hline & Male & Female \\
\hline Hong Kong-born & 62 & 51 \\
China-born & 61 & 45 \\
Total Australian population & 68 & 53 \\
\hline
\end{tabular}

Source: ABS 2003a 
Clearly, migration has a dramatic impact on Chinese women's employment patterns. Although they tend to be highly educated and accustomed to an active labour force role, migration to Australia is associated with a decline in labour market activity, and an escalation in domestic responsibilities. These patterns are rarely acknowledged by the Australian government, or by the research it cites as showing the success of skilled migrants. This oversight is partly due to researchers' primary focus on human capital criteria. Individuals are typically compared on the basis of occupational skills, English ability or visa category, which are seen as the major determinants of employment success. Rarely is gender used to compare outcomes (with the exception of Cobb-Clark 2001; Cobb-Clark and Chapman 1999).

However, gender is important because men typically possess higher levels of occupational and English skills than women, and thus are more likely to enter the country through the skilled migration program. In contrast, women are more likely to migrate on the basis of family relationships. ${ }^{5}$ The experiences of migrating spouses (80 per cent of whom are women in the LSIA) are often neglected completely, as most of this literature examines outcomes for primary applicants only (e.g. Cobb-Clark 2000; Cobb-Clark and Chapman 1999; VandenHeuvel and Wooden 1999, 2000). ${ }^{6}$

Of course, these gender differences in skill levels and visa categories are not random, but reflect broader social and cultural factors which shape men and women's educational and employment opportunities, and their domestic responsibilities. Ignoring gender differences in employment outcomes therefore produces a distorted account of migrant experiences (for a more detailed account of the neglect of gender in LSIA studies, see Ho and Alcorso 2004). The next section uses qualitative interview data to explain why these shifts in women's employment activity occur. 


\section{'I give up my career because anyway I'm a woman': Migration and mothering}

In many ways, the act of migration itself causes the decline in women's labour force activity. While men's careers are often a key part of households' decision to migrate, migrant women often find themselves in secondary, supportive roles. While men's priorities in the new country generally revolve around finding employment, women usually devote themselves primarily to facilitating the family's settlement in a new country. This entails practical tasks such as arranging housing and education for the children, as well as the emotional work of re-establishing social networks and supporting family members in their cultural adjustment to a new environment (Lee et al 2002; McLaren and Dyck 2004). Consequently, the act of migration itself often results an escalation in women's roles as wives and mothers, and a concurrent reduction in their role as income earners.

The escalation in women's 'mothering' roles is exacerbated by the loss of domestic support, such as paid domestic workers and extended family members (Man 1997; Meintel et al 1987; Salaff and Greve 2004; Yeoh and Khoo 1998; Zhou 2000). In Hong Kong and China, it is not uncommon for middle class families to employ a domestic worker. In Hong Kong, these are typically women from poorer countries such as the Philippines and Indonesia, and on the mainland, women from rural areas. In addition, following Confucian tradition, Chinese families are typically close-knit, with extended family members commonly living under the same roof or within close proximity. Childrearing is therefore a shared affair, with grandmothers in particular playing a key role in daily household activities. These domestic arrangements allow Chinese women to continue working full-time even when they have young children. Additionally, in urban China, workplaces commonly provide affordable child-care for employees (Salaff and Greve 2004; Zhou 2000). After migration, women are left with sole responsibility for household labour, which is keenly felt immediately after arrival, when the work of family maintenance is particularly demanding. 
These were very common experiences among my respondents. Most were highly educated, and prior to migration, had been active labour force participants pursuing professional careers. However, after migration to Australia, the challenges of settling in a new country and the loss of domestic support saw most of the women focusing their energies on their families, withdrawing completely from paid work or limiting themselves to part-time work. Table 4 shows the movement of the majority of my respondents from full-time work before migration, to mostly part-time work at the time of interview. For many, part-time work came after long periods out of the workforce, in the initial settlement period.

Table 4: Labour market status of respondents, before and after migration

\begin{tabular}{llcc}
\hline & & $\begin{array}{c}\text { Hong Kong } \\
\text { respondents } \\
\text { N=22 }\end{array}$ & $\begin{array}{c}\text { PRC respondents } \\
\mathbf{N = 2 2}\end{array}$ \\
\hline Pre-migration & Employed full-time & 20 & 21 \\
& Not employed & 2 & 1 \\
\hline Post-migration* Employed full-time & 6 & 8 \\
& Employed part-time & 13 & 9 \\
& Not employed & 3 & 5 \\
\hline
\end{tabular}

* at time of interview

Many of my respondents described their shock at suddenly being responsible for all the housework, and laughed at how they had to quickly acquire the skills to complete tasks that they had previously only managed, rather than actually performed. For example, Rose, ${ }^{7}$ a former travel agent from Hong Kong, spoke about how she had to start cooking the evening meal in the middle of the afternoon, as her kitchen skills were so underdeveloped when she first arrived in Australia.

The first year, I was so busy because I was not used to cooking, doing housework and all that, because in Hong Kong labour is cheap and I've got two maids to help me... So once I migrate here then I have to get used to doing housework, cooking and all that. And at the 
beginning I have to start the meal at three o'clock [laughs]. When I had to prepare the dinner, start three o'clock!

Sai, who had enjoyed generous occupational welfare as a university lecturer in China, said that her employer had assigned a live-in domestic worker to help her when she had her baby, so she too, never developed household skills.

In China it's different. When I had a baby, I had a houseworker help me at home. All the time, seven days a week. So I needn’t do any housework. Even when I arrived here I don't know any cooking. I don't know how to sew... Now I do all the things [laughs]. Never get anybody to help.

In many ways, new domestic arrangements in Australia expose the underlying gender inequalities in Chinese households, that prior to migration, were masked by women's access to domestic help. However, while assistance from hired domestic workers and relatives allowed women to spend more time at work, it did not remove their ultimate responsibility for household labour. Although they were able to outsource this work (notably, to female domestic workers and female relatives), they were still responsible for its overall management. In Australia, women are responsible for performing domestic labour as well. Meanwhile men, not accustomed to doing domestic work, experience no change in their household duties.

For most of my respondents, the loss of domestic support occurred just at the time when it was most needed - immediately after arrival in Australia. The disruptions and emotional stress of migration experienced by all family members intensified women's 'mothering' work. For example, Rose felt compelled to cease paid work after arriving in Australia for the sake of her three children. Young adolescents at the time of migration, her children were not happy about moving to Australia, and Rose felt she should devote most of her time to helping ease their transition. Therefore she decided to be a full-time housewife during her first two years in Australia.

Once I decided to come to Australia, I know I have to give up my career completely... doesn't matter, I give up my career because anyway I'm a woman, so I'm a housewife, so I 
should take care of the children and the house and all that...I think it's better to stay because at that time my children are not very happy, because they lost all their friends and they got nobody here. So they don't like it, so I think I better stay at home.

It is interesting that Rose explains her decision by invoking gender roles, stating that the appropriate role for a woman is to take care of the children and the house. In Hong Kong, supported by two paid domestic workers, she had worked full-time and often attended work-related social activities in the evenings and on weekends. Only after migration did she feel that her proper role was within the home. Migration therefore changed her perception of her own gender identity - being a woman now meant being a housewife, whereas before she had seen herself as a 'career woman'.

When Rose did seek employment in the travel industry, she was unsuccessful. She explained that she had lost all her work connections, and that in the years she had been out of the workforce, a lot of things had changed - 'everything is computerised and all that'. At the time of interview, Rose was working part-time as a home-based child carer, a job that was poorly paid (she earned $\mathrm{A} \$ 3.30$ per hour, per child), but one she enjoyed nevertheless.

Wendy, a former nurse in Hong Kong, also ceased paid work after migration, spending the first two years 'helping myself and my kids settle down here in Australia'. Away from her extended family, Wendy struggled with having to take primary responsibility for the children's welfare, and with the general demands of life in suburban Sydney, especially learning to drive and navigating around the city. Similarly, Sarah, a former accountant in Hong Kong, had not done any paid work since arriving in Australia a year and a half earlier. She explained that as her baby was only a few months old when she arrived, she felt she needed time at home to take care of him and adjust to a new country. When Sarah did seek paid employment after several months, she could not find a suitable job, which she partly attributed to her inability to work full-time.

Overall, migration to Australia dramatically changes women's working lives. While they were accustomed to working full-time prior to migration, the disruption of family life created by the act of migration often necessitates an escalation of their domestic roles. 
Chinese women find themselves spending much more time at home providing emotional support to family members and re-establishing the daily operation of the household in a new context.

When Chinese women do engage in employment, the 'double burden' of work and family responsibilities seriously constrains the types of jobs they are able to do, and the career opportunities they are able to accept. As the next section explains, in this sense Chinese migrant women assimilate into the highly gendered labour market practices that are experienced by the majority of Australian women.

\section{'Maybe if I was a man...': Chinese women's double burden}

Like women in other western countries, Australian women have dramatically increased their participation in the workforce, from 25 per cent just after World War II to more than double that level today (56 per cent in November 2002) (Burgess et al 2003: 141). However, this growth in women's employment levels has not been accompanied by significant re-organisation of domestic responsibilities. In the late 1990s, the Australian Bureau of Statistics Time Use Survey found that there was a 30/70 split between men and women in time spent on household work, ${ }^{8}$ and that between 1987 and 1992, Australian men did not increase their domestic activities overall, except for a slight increase in childcare (Bittman and Pixley 1997: 96). Clearly, whether they engage in paid work or not, women are seen as responsible for household labour. As Pocock (2003:2) comments, the "cultural constructions of "proper mothers", and "proper carers" have not changed commensurate with change in their roles in paid work. Many still think of a good mother as an ever-available generous carer.'

Despite the vigorous public discussion about 'family friendly' workplaces in Australia (e.g. HREOC 2002; DEWR 2003), there is little evidence that parents are experiencing improvements in their ability to balance work and family responsibilities. As Table 5 shows, in 1995, more than twice as many Australian employees reported that their satisfaction with work and family had decreased as those who said it had increased. 
Table 5: Change in satisfaction with work/family balance over past twelve months (employees with de pendants), $1995(\%)$

\begin{tabular}{lccc}
\hline Satisfaction & Women & Men & All \\
\hline Increased & 17 & 13 & 15 \\
Decreased & 30 & 34 & 32 \\
No change & 51 & 52 & 52
\end{tabular}

Source: AWIRS, 1995, cited in Pocock, 1998: 600

It is no surprise then, that many women leave the workforce entirely when they have children, or work in part-time jobs. In round terms, half of all women employed during pregnancy do not return to employment within 18 months in Australia, and when they do, the majority return part-time (Buchanan and Thornthwaite 2001: 30). In 2001, 62 per cent of women with children (16 years and under) worked part-time (Hazelhurst 2003: 12). Many part-time jobs are also casual: more than 30 per cent of employed women are in casual jobs (Watson et al 2003: 68).

While part-time and casual work can provide flexibility for juggling paid and unpaid responsibilities, it is also characterised by lower job security and remuneration relative to full-time work. Part-time workers also have less access to participatory mechanisms in the workplace, such as communication, meetings and consultations (Markey et al 2003), as well as important workplace processes such as training, promotion and bargaining (Pocock 1998: 587). Overall, women's concentration in part-time and casual employment prevents them from investing in their careers as fully as men do. As Pocock (2003: 5) argues, women's concentration in part-time and casual positions has 'entrenched the peripheral status of carers in many workplaces'.

Migrant women are no exception to these patterns. For Chinese women, accustomed to having full-time employment throughout their working lives, the double burden is often experienced more sharply in Australia than in their home countries. They often feel compelled to give up particular types of jobs or career opportunities, and within the jobs 
they hold, feel constrained by having to arrange their working lives around their household responsibilities. ${ }^{9}$

For example, when Margaret, a secretary from Hong Kong, decided to return to the workforce after several years as a full-time mother in Australia, her job-search was heavily defined by her child-care responsibilities. She told me she found herself negotiating with one prospective employer for flexible hours before she had even secured the position. During the job interview, she requested working hours compatible with the school day:

Luckily, the one interviewing me, she also had a family...So I was telling her, my son, my kids are at the school just across the road. I said it would be good if I can pick them up they finish at $3.15 \ldots$ So if I could work up to like 8.30 to 3.30 . Of course you don't have to pay me full wages, just pay me proportionally, so I don't have to hire after school care, and it would really help me tremendously. So I gave them this term, and she was a very understanding lady, because she had a family.

Shu-lan, mother of three school-age children, also arranged her paid work around domestic responsibilities, transferring from full-time work in Hong Kong to shift work in Australia. At the time of interview, Shu-lan was working as a waitress in a 24 hour restaurant and bar between 9pm and 2am, 'because when I work this shift, it means I can cook dinner for the kids, and then after they finish I can go to work.'

Some respondents spoke of how family responsibilities precluded them from taking up potentially rewarding opportunities, such as establishing a small business. For example, Belinda had worked as a waitress in her brother's Chinese restaurant since arriving in Australia from Hong Kong 14 years earlier. After the first five years, she tried to open her own restaurant, but closed it a few years later after her daughter was born. Not feeling able to care for her child and operate her own business, she returned to her brother's restaurant. Belinda told me she could not consider opening another business, although her engineer husband had recently established his own telecommunications business, installing cabling and telephone systems. Belinda offered this explanation: 
Maybe - I am a woman, so that's why. Maybe if I [was] a man or I got the family background to support all that - maybe...

Indeed, in addition to Belinda's own job in the restaurant, she sometimes helped in her husband's business, buying and collecting stock, passing on messages from customers, and so on.

Others stated that family obligations prevented them from pursuing particular employment opportunities, or prevented them from participating in some work activities because they were unable to work long hours. For instance, Susan, a business analyst from Hong Kong, was happy with her job, but felt that family responsibilities imposed a glass ceiling on her career aspirations. Having graduated with a degree in Commerce from a Canadian university, she was well equipped for a career in the corporate world, and had reached a senior position within the personnel department of Microsoft before migrating to Australia. In Australia however, her career aspirations had shrunk.

Although I got some career aspiration, but due to family commitments, sometimes at the moment I take a job as a job - as a way of making a living. Not really so much on career, because I can't spend ten, eleven hours in the office. I have to go - quarter to six I have to pack up and rush home, look after my family... I can't afford to be a career woman.

Susan explained that while her husband was happy for her to have a job, this did not obviate her from meeting her domestic responsibilities. She said her husband would be happy as long as 'you can manage both sides'.

Overall, Chinese women's careers in Australia are much more constrained by domestic responsibilities than they had been before migration, and the jobs they found themselves in often held little prospect for career advancement. The next section outlines the personal implications of this shift in women's roles.

Feminisation of roles: back to traditional gender roles 
The shift in Chinese women's roles has implications for the social relations of their households. While Chinese men are typically able to consolidate their role as breadwinner and head of the household after migration, women often feel, for the first time in their lives, a sense of dependence on their husbands, both economically and socially (Lary et al 1994; Man 1995, 1997). Some women are surprised to find that Australian norms about women's roles seem more conservative than what they were accustomed to in Hong Kong and China, where mothers are expected to continue paid work.

Among my respondents, this dependence on partners was a source of frustration, particularly in the early period. For example, Nicola, an ambitious young high school teacher, was accustomed to being extremely independent in Hong Kong, but after migrating to join her Australian husband, she found herself relying on him for everyday items:

I was really struggling when I first came...I wasn't allowed to have a credit card or a mobile phone, because I couldn't produce the documents to let them give it to me. It was so frustrating because in Hong Kong I had three credit cards, and a mobile, and email. I felt really dependent, when I was used to doing it all by myself. My husband was happy to pay but I didn't feel good. The car was registered under his name, when I used to drive in Hong Kong as well. Because I had a really good job before - teaching in an international school is just about the best teaching job you can get. I had a really independent role in Hong Kong, and that was reversed when I came here.

Others felt that their social circles had become centred entirely around their husbands, because the men met more people through work or had been in Australia longer than they had. The women were now primarily seen as wives rather than independent individuals. For example, Jackie, a high school teacher who migrated to Australia from China five years after her husband, found that when she arrived, she slotted into his social circles, and did not have much time to develop her own. She commented, 
I haven't got any more close friends, my friends - just my friends. Most of friends are my husband's friends...we have a lot of friends in China... [and my family] they're all in China. So this is big problem.

Jackie was frustrated that her social circle did not comprise people she herself had chosen. Throughout the interview, whenever she referred to 'my friends', she stopped abruptly to correct herself with the phrase - 'my husband's friends'.

Sarah, an unemployed accountant from Hong Kong, also found herself isolated in Australia, having migrated 12 months after her husband. While her husband, a computer programmer, had relatives in Australia and friends from an IT course he had completed, Sarah had only met other mothers in playgroups. She felt she would not be able to develop her own social networks until she had found paid work. Until then, she believed she could never be truly integrated into Australian society. In Hong Kong, Sarah had the help of a paid domestic worker and her mother-in-law, both of whom lived with her family. This allowed her to work full-time even after her baby was born. In Australia, however, a combination of child-care responsibilities and lack of success in the labour market resulted in Sarah's total re-orientation from work to family life. As she said,

You need to change, to adjust yourself, to change your attitude, change your focus. Then life is better, easier. Because it's completely different...it's different formats of life... When you work you will be free, away from your kids... The style here now is, you just focus on your baby. That's all.

For some respondents, changes in gender relations within the household partly reflected what they saw as the dominant gender relations within Australian society. These women felt that working women in Australia generally faced heavier burdens compared to those in Hong Kong or China. For example, Susan, a business analyst from Hong Kong, expressed her surprise at the tendency for Australian women to leave the workforce after having children, a practice not common in Hong Kong:

I would think that the women in Hong Kong are more independent than the women here. Quite a lot of the women in Australia, I find, once they have children, they stop working. 
But whereas in Hong Kong, no matter what kind of job you have - you can have some clerical job, you can be a manager - but still a lot of women, even though they have children, they still keep on working, whereas in Australia, I found, quite a lot of my colleagues, their wives stop working once they have baby. This is what I observe.

Anita, a systems analyst from Hong Kong, explained that Hong Kong's labour shortage inculcated a work culture that was very accepting of women in senior positions, particularly in the public sector. Australia, by contrast, was 'still very much a man's empire', with women constrained by child-care responsibilities:

Hong Kong is a society in which you get more opportunities - before 1997. At the time, there's a real lack of resources - they just grab whoever is able, they couldn't discriminate. Another thing is the taxes are really low and most women can get domestic help...But here, after my boy is born, I decided to stay home and take care of him. I just can't get a domestic helper and I don't want to put him in day care. And the tax is not attractive. If I go back to work as a manager, if I get a nanny, most of my wage would go to her.

Respondents from China expressed similar sentiments, stating that they felt that China offered greater gender equality in the workplace compared to what they had seen in Australia. For example, Jian, a metallurgical engineer, was proud to have studied under a renowned female scholar at university, and always believed that women could do anything that men could. In Australia, however, she was disappointed to observe that engineering seemed to be a 'men's field'.

Similarly, when I asked Ying, a former teacher, to compare the roles of men and women in China and Australia, she replied that in Australia, women were more 'second class':

[In China] It's really easy now for a woman to go to the higher position, and always I feel very equal - the pay - if you the same time, the same qualifications, the same position you got the same pay. And promotion. I never feel anything - the women are the second class. But I feel something in Australia. Those they always say 'sweetheart'. It's a polite way to do it, but actually it's not real [laughs]. In looking for work you can always see the man in the higher position. I think China is much better. 
For many Chinese women in Australia, migration entails a feminisation of roles. Accustomed to combining full-time work with motherhood, these women have to readjust their expectations regarding their careers, which in Australia need to be more heavily structured around domestic responsibilities. For some, this is experienced as returning to more traditional gender roles which delineate men's activities in the public sphere and women's in the private sphere.

\section{Conclusion}

The experiences documented in this paper challenge prevailing understandings of migrant employment in Australia in two ways. First, while the Australian government, relying on economistic research informed by human capital theory, presents a 'success story' narrative of skilled migration to Australia, this is a simplification of a much more complex reality. While orthodox explanations draw a causal link between individuals' human capital and their employment outcomes, this ignores the gendered character of labour market experiences. Placing individuals in their household context shows that men and women have very different relationships with the labour market, and even skilled women may not be able to utilise their human capital if they cannot re-establish effective work-care arrangements.

Second, prevailing accounts of migrant employment, reliant on quantitative data, cannot show how employment patterns are experienced by migrants. Even if the quantitative literature were to document gender differences in labour market participation, for example, this would hardly even begin to explore the impact of migration on the working lives of migrant women and men. As my interviews with Chinese women show, changing relationships with the labour market reflect a much deeper evolution of migrant women's gender identities. Migration to Australia means fundamental shifts in how Chinese women identify with their various roles as wives, mothers and income earners, and changes their personal priorities and aspirations in ways that cannot be captured in statistics. 


\section{References}

ABS (Australian Bureau of Statistics) (2003) 2001 Census Expanded Community Profile, cat. no. 2005.0 .

Bauer, J., F. Wang, N. E. Riley and X. Zhao (1992) 'Gender Inequality in Urban China', Modern China, 18: 333-370.

Bittman, M. and J. Pixley (1997) The Double Life of the Family, Sydney: Allen \& Unwin.

Buchanan, J. and L. Thornthwaite (2001) 'Paid Work and Parenting: Charting a New Course for Australian Families', Sydney: ACIRRT - a report for the Chifley Research Foundation.

Burgess, J., W. Mitchell and A. Preston (2003) 'The Australian Labour Market in 2002', The Journal of Industrial Relations, 45(2): 125-150.

Chattopadhyay, A. (1997) 'Family Migration and the Economic Status of Women in Malaysia', International Migration Review, 31(2): 338-52.

Cobb-Clark, D. (2000) 'Do Selection Criteria Make a Difference? Visa Category and the Labour Market Status of Immigrants to Australia', The Economic Record, 76(232): $15-31$.

Cobb-Clark, D. (2001) 'Settling In: Public Policy and the Labor Market Adjustment of New Immigrants to Australia', Australian National University, December 17, http://econrsss.anu.edu.au/ dcclark/docs/papers/lsia_compare_13.pdf, accessed: 17 March 2003.

Cobb-Clark, D. and B. J. Chapman (1999) The Changing Pattern of Immigrants' Labour Market Experiences, discussion paper no. 396, Centre for Economic Policy Research, Australian National University.

DEWR (Department of Employment and Workplace Relations) (2003) Australian Workplace: Work and Family, http:/www.workplace.gov.au/Workplace, accessed: 18 November 2003.

DIMIA (Department of Immigration and Multicultural and Indigenous Affairs) (2001) 'DIMIA Fact Sheet 14: Migrant Labour Market Outcomes', http:/www.immi.gov.au/facts/14labour.htm, accessed 20 November 2001.

DIMIA (Department of Immigration and Multicultural and Indigenous Affairs) (2002)

The Longitudinal Survey of Immigrants to Australia, http://www.immi.gov.au/research/lsia/index.htm, updated: 1 March 2002. 
Halfacree, K. H. (1995) 'Household Migration and the Structuration of Patriarchy: Evidence from the USA', Progress in Human Geography, 19(2): 159-82.

Hazelhurst, D. (2003) 'Family and Work: Issues and Risks across the Life Course', paper for the Australian Social Policy Conference, 9-11 July, University of New South Wales.

Ho, C. and C. Alcorso (2004) 'Migrants and Employment: Challenging the Success Story', Journal of Sociology, 40(3): 237-259.

HREOC (Human Rights and Equal Opportunity Commission) (2002) Valuing Parenthood: Options for paid maternity leave, Interim Paper, http:/www.hreoc.gov.au/sex_discrimination/pml/index.html, accessed 17 November 2003.

Kofman, E. (2000) 'The Invisibility of Skilled Female Migrants and Gender Relations in Studies of Skilled Migration in Europe', International Journal of Population Geography, 6: 45-59.

Lam, L. (1994) 'Searching for a Safe Haven: The Migration and Settlement of Hong Kong Chinese Immigrants in Toronto', in R. Skeldon (ed) Reluctant Exiles? Migration from Hong Kong and the New Overseas Chinese. Armonk, NY: M.E. Sharpe.

Lary, D., C. Inglis and C. Wu (1994) 'Hong Kong: A Case Study of Settlement and Immigration,' in H. Adelman, A. Borowski, M. Burstein and L. Foster (eds) Immigration and Refugee Policy: Australia and Canada Compared. vol 2, Melbourne: Melbourne University Press, 405-444.

Lee, M., A. Chan, H. Bradby and G. Green (2002) 'Chinese Migrant Women and Families in Britain', Women's Studies International Forum, 25(6): 607-618.

Lee, W. K. M. (2002) 'Gender Ideology and the Domestic Division of Labor in Middleclass Chinese Families in Hong Kong', Gender, Place and Culture, 9(3): 245-260.

Mak, A. S. (2001) Relocating Careers: Hong Kong Professionals and Managers in Australia. Hong Kong: Centre of Asian Studies, The University of Hong Kong.

Man, G. C. (1995) 'The Experience of Women in Chinese Immigrant Families: An Inquiry into Institutional and Organizational Processes', Asian and Pacific Migration Journal, 4(2-3): 303-326. 
Man, G. C. (1997) 'Women's Work is Never Done: Social Organization of Work and the Experience of Women in Middle-class Hong Kong Chinese Immigrant Families in Canada', Advances in Gender Research, 2: 183-226.

Man, G. C. (2004) 'Gender, Work and Migration: Deskilling Chinese Immigrant Women in Canada', Women's Studies International Forum, 27(2): 135-148.

Markey, R., J. Kowalczyk and S. Pomfret (2003) 'Part-time Employment, Gender and Employee Participation in Illawarra Workplaces', The Journal of Industrial Relations, 45(1): 48-66.

McClaren, A. T. and I. Dyck (2004) 'Mothering, human capital, and the "ideal immigrant"', Women's Studies International Forum, 27(1): 41-53.

Meintel, D., M. Labelle, G. Turcotte and M. Kempineers (1987) 'The New Double Workday of Immigrant Women Workers in Quebec', Women's Studies, 13(3): 273-293.

Pe-Pua, R., C. Mitchell, R. Iredale and S. Castles (1996) Astronaut Families and Parachute Children: The Cycle of Migration between Hong Kong and Australia. Canberra: Australian Government Publishing Service.

Pocock, B. (1998) 'All Change, Still Gendered: The Australian Labour Market in the 1990s', Journal of Industrial Relations, 40(4): 580-604.

Pocock, B. (2003) The Work/Life Collision: What work is doing to Australians and what to do about it. Sydney: Federation Press.

Raghuram, P. and E. Kofman (2004) 'Out of Asia: Skilling, Re-skilling and Deskilling of Female Migrants', Women's Studies International Forum, 27(2): 95-100.

Richardson, S., F. Robertson and D. Illsley (2001) The Labour Force Experiences of New Migrants, Canberra: Australian Government Publishing Service.

Richardson, S., L. Miller-Lewis, P. Ngo and D. Illsley (2002) The Settlement Experiences of New Migrants: A Comparison of Wave One of LSIA 1 and LSIA 2, report prepared for the Department of Immigration and Multicultural and Indigenous Affairs, Commonwealth of Australia.

Salaff, J. and A. Greve (2003) 'Gendered Structured Barriers to Job Attainment for Skilled Chinese Emigrants in Canada', International Journal of Population Geography, 9: 443-456. 
Salaff, J. W. and A. Greve (2004) 'Can women's social networks migrate?' Women's Studies International Forum, 27(2): 149-162.

Shihadeh, E. S. (1991) 'The Prevalence of Husband-Centred Migration: Employment Consequences for Married Mothers', Journal of Marriage and the Family, 53(2): 432-44.

Smits, J. (1999) 'Family Migration and the Labour-force Participation of Married Women in the Netherlands, 1977-1996', International Journal of Population Geography, 5: 133-50.

VandenHeuvel, A. and M. Wooden (1999) New Settlers have their Say: How immigrants fare over the early years of settlement: an analysis of data from the three waves of the Longitudinal Survey of Immigrants to Australia, Canberra: Department of Immigration and Multicultural Affairs.

VandenHeuvel, A. and M. Wooden (2000) 'Immigrants' Labour Market Experiences in the Early Settlement Years', Australian Bulletin of Labour, 26(1): 59-69.

Watson, I., J. Buchanan, I. Campbell and C. Briggs (2003) Fragmented Futures: New Challenges in Working Life. Sydney: The Federation Press.

Yeoh, B. S. A. and L. Khoo (1998) 'Home, Work and Community: Skilled International Migration and Expatriate Women in Singapore', International Migration, 36(2): $159-184$.

Zheng, W. (2000) 'Gender, Employment and Women's Resistance' in E. J. Perry and M. Selden (eds), Chinese Society: Change, Conflict and Resistance, London: Routledge.

Zhou, Y. (2000) 'The Fall of "The Other Half of the Sky"? Chinese Immigrant Women in the New York Area', Women's Studies International Forum, 23(4): 445-459. 

${ }^{1}$ The term 'feminisation' is not intended to naturalise women's domestic roles, or endorse gendered
divisions of labour which result in women's responsibility for household work, but rather seeks to reflect the social construction of gender roles, clearly highlighted in the dramatic changes in women's roles and identity that are experienced with migration.

${ }^{2}$ The LSIA surveyed migrants entering Australia between September 1993 and August 1995. Wave 1 of the survey was conducted six months after arrival, Wave 2, 18 months, and Wave 3, three and a half years after arrival. Both the primary applicants for migration and migrating unit spouses were surveyed (see DIMIA 2002, for more information about the LSIA).

${ }^{3}$ This paper focuses on the intersection of work and family concerns in shaping women's employment experiences. For reasons of space, I do not discuss the other important factors documented in the literature (discrimination, language, qualifications recognition, and so on).

${ }^{4}$ It is not surprising that migrating unit spouses experience a more dramatic reduction in labour force participation relative to primary applicants. Under the Australian migration program, primary applicants (applying through the Skilled migration stream) must meet rigorous requirements relating to educational and occupational skills, while spouses are not subject to these criteria. Therefore primary applicants tend to be more employable than their spouses. Given that the majority of spouses are female, this raises broader questions about the gendered employment outcomes of migrants to Australia.

${ }^{5}$ However, it is important to avoid drawing clear correlations between vis a category and skill level (Kofman 2000; Man 2004). Many highly skilled women migrate as dependents, for example, simply because their husband's skill profile more closely matches Australian migration requirements, or because they arrive sometime after their partners, who sponsor their migration. These patterns reflect the tendency for migration to be male-initiated, a phenomenon that has been widely documented (Chattopadhyay 1997; Halfacree 1995; Lee et al 2002; Shihadeh 1991; Smits 1999; Yeoh and Khoo 1998). This highlights the importance of analysing human capital characteristics within broader social contexts, for example, gendered power relations within households.

${ }^{6}$ This exclusive focus on primary applicants is also evident in much of the literature on skilled international migration, for example research on inter-company transfers, which largely ignores experiences of accompanying spouses (generally women) (Kofman 2000).

${ }^{7}$ All names of respondents cited in this paper are pseudonyms, and some details have been changed to preserve anonymity.

${ }^{8}$ This is based on the broadest definition of domestic labour and includes 'outdoor' tasks like house maintenance and car cleaning, in which men specialise.

${ }_{9}^{9}$ This is not to say that similar constraints are not felt by working women in Hong Kong and China. Lee (2002: 255) shows that in Hong Kong the middle-class ethos is to prioritise men's careers over women's, and that women are generally less preferred as workers because of their family responsibilities. In China, despite official egalitarianism in government policy, women are still discriminated against in the workplace, and in recent years have been urged back to the home to ease escalating national unemployment (Zheng 2000). However, most of my respondents agreed that such pressures were more keenly felt in Australia. 